PREGLEDNI

ČLANAK

\title{
The importance of intercultural competence in foreign language teaching, with reference to tourism curricula in higher education
}

\author{
Značaj interkulturne kompetencije u nastavi \\ stranog jezika, sa osvrtom na značaj za \\ kurikulume turizma u visokom obrazovanju
}

\author{
Mladen Tomić, Fakultet za sport i turizam, Novi Sad \\ Danijela Čolić, Fakultet za sport i turizam, Novi Sad
}

ABSTRACT

Keywords: Foreign language, Curriculum,

Tourism, Intercultural competence

SAŽETAK

Ključne reči: strani jezik, kurikulum,
Over the past several decades, tourism industry has seen constant growth on a global scale, not only in terms of the number of international tourists and the number of persons employed in tourism, but also in terms of its global GDP share. Such a growth entails the need for a greater number of qualified tourism experts, as well as for more advanced language competences, but also those intercultural and communicative competences that correspond to pertaining educational profiles and professional challenges. Most tourism curricula at European universities contain one or more foreign language courses. That language is most commonly English, while languages most commonly featured as second are German, Spanish and Italian. It is questionable whether, besides professional language competences which universities target as their primary outcome, those courses can adequately prepare future tourism professionals for work in their field or if they offer only general linguistic knowledge. The goal of this paper is to point to the necessity to include intercultural competences in foreign language teaching, so the future tourism professionals would master not only communication skills, but also those skills that would enable them a meaningful engagement in the contexts that require intercultural interaction.

U toku poslednjih nekoliko decenija, industrija turizma na globalnom nivou beleži konstantan rast, kako po broju međunarodnih turista i broju zaposlenih u turizmu, tako i po učešću u BDP-a na globalnom nivou. Ovakav porast podrazumeva potrebu za većim brojem kvalifikovanih stručnjaka u turizmu, kao i za naprednijim jezičkim kompetencijama, ali i onim interkulturološkim i komunikološkim kompetencijama koji odgovaraju ovakvim obrazovnim profilima i profesionalnim izazovima. Većina kurikuluma turizma na evropskim univerzitetima 
turizam, sadrži jedan ili više stranih jezika. Najčešće je reč o engleskom jeziku, a kao drugi strani jezik interkulturna često se sreću nemački, španski i italijanski. Pored užestručnih jezičkih kompetencija koje kompetencija univerzitetski silabusi imaju za svoj primarni ishod, postavlja se pitanje da li ti kursevi u dovoljnoj meri pripremaju stručnjake u turizmu za rad u profesiji ili im pružaju samo opštejezička znanja. Cilj ovog rada je da ukaže na neophodnost uključivanja interkulturne kompetencije u nastavu stranog jezika, kako bi budući poslenici u turizmu ovladali ne samo komunikacionim veštinama, nego i onim veštinama koje im omogućuju smisleno angažovanje u kontekstima koji zahtevaju kulturološku interakciju.

\section{Introduction}

A number of factors have influenced the fact that tourism has become one of the most notable mass phenomena with a significant impact on people's everyday lives and an influence on economies of a number of countries (Čolić \& Tomić, 2013). Accordingly, such a massive industry requires a great number of employees who will need to possess certain skills and knowledge in order to offer the best possible service and remain competitive. One of the basic prerequisites for successful communication in the sphere of tourism is mastery of foreign languages. Tourism industry places high demands on its employees in terms of communicative and intercultural competence, as well as expecting them to speak at least one foreign language (Čolić \& Tomić, 2013). In today's globalised world, knowledge of at least one foreign language (especially English) is taken for granted, with other languages gaining prominence, as well. There are almost no business fields that can thrive without foreign languages and this is particularly true of the tourism industry.

With the continued expansion of the European Union, European language policies are moving towards teaching 'at least two foreign languages from a very early age' and describe the knowledge of foreign languages as a 'basic skill' (Božinović \& Sindik, 2013). This tendency is supported by the public, as polls in the EU confirm the need to be able to speak more than one language, with $72 \%$ respondents agreeing that "everyone in the EU should be able to speak more than one language in addition to their mother tongue". While there have been improvements in the ways that languages are taught at the primary and secondary levels of education in the EU (especially in terms of the first foreign language), there is a need for increasing the level of involvement of universities, especially in view of increased mobility, migration, and bi- or multilingualism across Europe (European Commission, 2018).
The Common European Framework of Reference for Languages defines communicative language competence as an outcome arising from the acquisition of foreign languages. The notion of communicative competence was introduced in the early 70 s of the $X X$ century and was established as the primary goal of foreign language teaching until as late as the 90s. However, during the 90s, intercultural aspects of communication in a foreign language gained more attention. In addition to the obvious presence of other cultures arising from the processes of globalisation, migration and increased mobility, the reason for this new perspective was also the wish to avoid trivialising the teaching of foreign languages, which was noticeable in certain forms of the communicative teaching model $(\mathrm{Hu}, 2010)$. The goals of teaching foreign language have since been redefined accordingly. In addition to the functional-communicative aspects, some abilities have been included, such as empathy, change of perspective, relativization of ethnocentric perspective, etc.

A very important role in tourism, in addition to the linguistic competence, is played by intercultural awareness and intercultural competence, which are very desirable complementary elements and which can be developed through teaching of foreign languages. This article explores different implications of the notion of intercultural competence and assesses its effect on a cultural component of foreign language courses at university studies of tourism.

\section{Intercultural competence}

Ever since the globalisation took place, we have increasingly been encountering the notion of intercultural competence and the recommendations for mastering it in order to function as successfully as possible in today's multicultural world. In the broadest sense of the word, intercultural competence can be defined as a complex 
of abilities required for efficient and purposeful acting in interactions with persons who are linguistically and culturally different from us (Fantini, 2000). However, if we tried to create an overview of discussions on the topic of intercultural competence, the volume of such material would sooner cause us bewilderment than lead us to understand as to what this notion actually represents, seeing as different scientific disciplines have described this concept in different terms, developing a great number of its models. Robert Gardner, an American social psychologist was among the first to formulate the notion of intercultural competence in 1962. He suggested the concept of a "universal communicator", i.e. an individual with a particular ability of intercultural communication and a range of personal traits, such as integrity and stability, extroversion, socialisation in universal values and including special intuitive and even telepathic (!) and intuitive abilities (Gardner, 1962:248).

Unlike the period when this notion was first studied, the increase of intercultural interaction in society and economy is in the public's focus and good examples of such interaction are migration and multiculturality. Contacts with political interests (education policies, integration policies and foreign policies) and with the possibility of economic exploitation contribute to the intensity and fervour of this debate (Rathje, 2006).

Still, even after half a century, scientists are not giving up on their efforts to define this concept, although it appears that, despite all attempts, no universal definition can be formed. On the one hand, known models include affective and cognitive aspects of intercultural competence, as well as the aspects linked to behaviour. On the other hand, in addition to these models that concern an individual, there are also situational and interactive models, which, besides the competences of an individual, focus on the conditions of the interaction or aspects of interaction between the participants and the situation (Thomas, 2003)

Indeed, the competences that refer primarily to those communicational skills and usages of a language that do

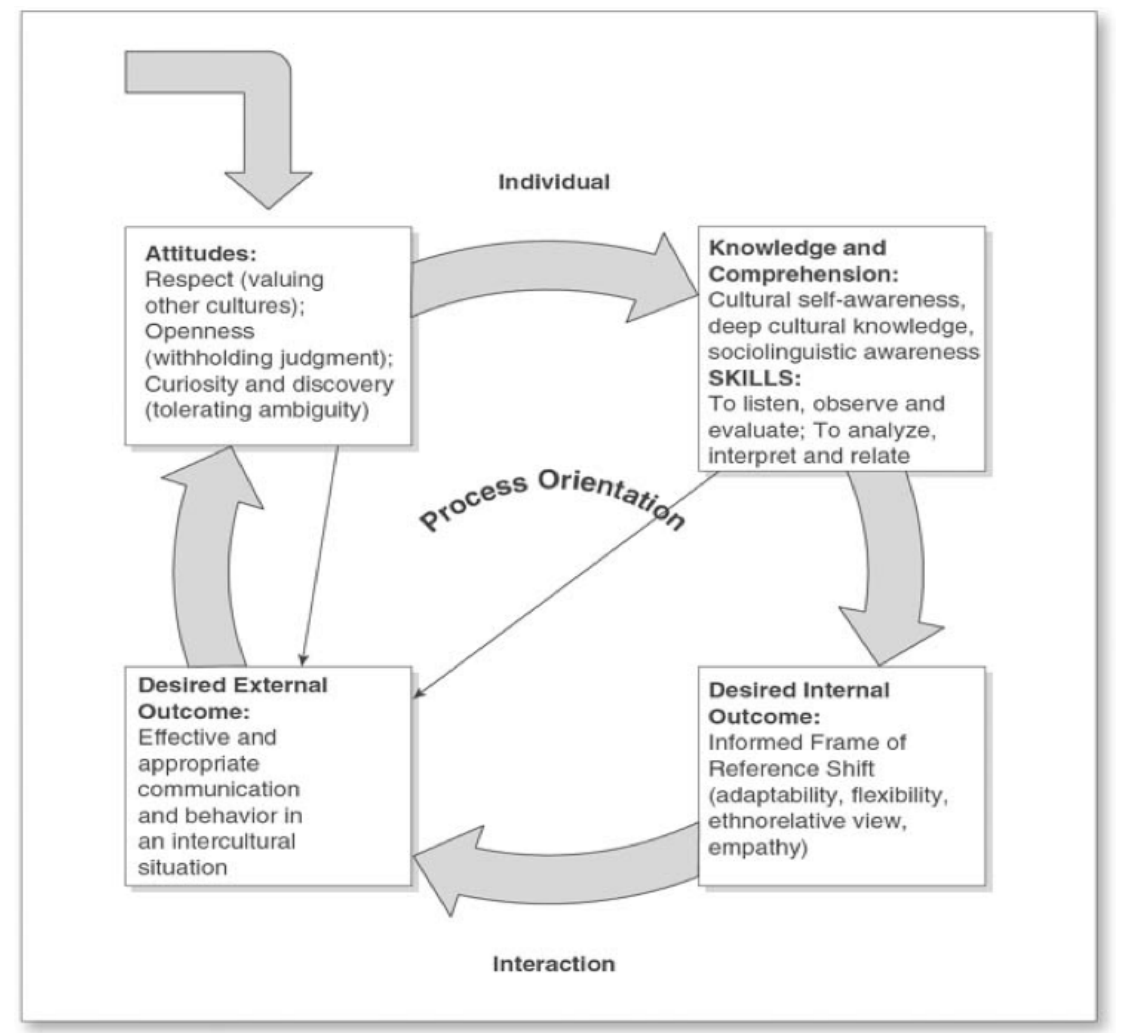

Figure 1. Deardorff's Process Model of Intercultural Competence

(Source: Deardorff, 2006:242)

not correspond to a purely transactional and mathematical use oflanguage can be termed extralinguistic competences, of which intercultural competences are a subset. In the context of this paper, extralinguistic competences include all the competences arising from decodification and interpretation of culturally-specific codes manifested in the process of communication, including, but not limited to culturally-specific paradigms, as well as paralinguistic patterns and occurrences. 
Arguably, it is impossible to exclude cultural content from teaching a language (and likewise, each culture is best and most immediately perceived through its language). The fact that the said content is not called or recognised as such does nothing to prevent it from actually being taught. Still, it has long been established that recognising the culture lessons for what they are and making the most of them enhances the language learning experience greatly (Valdes, 1990).

Fundamental differences in understanding of the concept of intercultural competence inevitably lead to different answers to the question - what particular competences is it composed of and how can it be transferred or taught to others? One of the more widely accepted models of intercultural competence is proposed by Deardorff and includes four dimensions that are necessary (but not sufficient!): 1) attitudes (motivation), 2. Skills 3. Ability to reflect on goals and personal outcomes of intercultural competence, 4. Constructive interaction as an external outcome of intercultural competence (Deardorff, 2006).

Teaching foreign languages is a "fertile ground" for stimulation and development of intercultural competence. "Foreign language classes is the very place where skills used to transcend borders between different cultures are acquired (...) and language learning that favours only the linguistic dimension is an amputated language learning" (Blayhl, 1994:9).

Claire Kramsch recognises language as a social practice and culture as the very core of language teaching. Moreover, she understands cultural awareness (which is the basis for intercultural awareness and, in turn, intercultural competence) as an element that enables language proficiency and not as an expandable skill tacked on to the teaching of speaking, listening, reading and writing. (Knowles \& Kramsch, 1995)

The language goals as laid out in Standards for Foreign Language Learning (2006) are defined in terms of the $5 \mathrm{C}$ 's (Communication, Cultures, Connections, Comparisons, and Communities) that are conceived to guide learners towards becoming viable contributors to a linguistically and culturally diverse society. A culturally appropriate interaction, according to the Standards, occurs with two individuals engaging in a reciprocal conversation based on mutual understanding and an attitude of openness. Any curricula, therefore, based on the Standards, will be based on an inextricable link between language and culture.
The concept of intercultural competence has been established all over Europe as a relevant education goal and it has found its place in the foreign language curricula accordingly. This shows educational, political and didactic attempts to reflect the tasks of foreign language classes in the circumstances of globalisation and internationalisation processes. Still, in order to have theoretically grounded curriculum planning, consensusbased principles in terms of defining the goal and outcome of intercultural competence are still missing.

An increase of personal and/or media covered intercultural encounters that characterise today's European society poses a challenge to foreign language teaching in terms of providing the students with competences required to overcome the increasing social, ethnic, national, cultural and linguistic heterogeneity, as well in terms of teaching them how to manage different intercultural contacts in their future professional lives (Petrović, 2011).

Developing intercultural competence in foreign language teaching requires that it be contained in all segments of teaching - from the teaching content to the teaching goals, teaching materials and, lastly, evaluation of the teaching process.

\section{Intercultural competence in foreign language teaching in tourism curricula}

The mentioned mobility trends and immigration processes in Europe also call for quality and educated staff that could cater to the diverse needs of customers in a manner that would be language-appropriate and culturally acceptable. This fact alone has made knowledge of languages one of the first employability skills in the sector of tourism. More than just a tool for doing business, language has become a crucial skill for participation in socially engaged and meaningful activities in a multilingual environment.

The fundamental role of a language professor today lies less in teaching a language as a mechanical system of communication. In fact, one could argue that the fundamental difference between training and education lies less in acquisition of skills not previously possessed by the trainee, but precisely in a conscious transformative engagement with the environment, as suggested by Holly (1990.)

Drawing on earlier authors to disassociate himself from the mathematical model of a language, Holly goes on 
to presume the existence of a hidden cultural charge that every language (and teaching thereof) necessarily carries, the message contained in any given language use being additional to its simple reference-value. Therefore, by learning another language, we do not merely learn to convey messages in a manner that an advanced algorithm might. Instead, we reach out to meet other societies, their norms, habits, complexities and internal relations.

Despite the potential dangers of the pitfalls of extended cultural contacts - such as, on the one hand, alienation from other cultures or, on the other side of the spectrum, succumbing to cultural imperialism (Holly, 1990), some of the benefits of acquiring a language through tourism-oriented curricula lie in overcoming of pure "translationism" (and the temptation of assumption of equivalence) through understanding of cultural nuances and challenges of translating them from/into other languages. Seeing as understanding a culture is important not only from the aspect of doing business, but also because of the fact that modern tourism tends to "sell" culture, cultural products and the very image thereof as a commodity. In the words of Thurlow and Javorsky, "tourism is a deeply "semiotic industry", committed to the production, commodification and representation of culture and cultural difference; language is clearly an essential resource in this cultural production' (Thurlow \& Javorsky, 2010). Thus, finding a way to clearly and effectively communicate interculturally by gaining a broader understanding of cultural differences may help students to challenge and grasp many aspects of tourism, including the basis for, processes and outcomes of its management (Liburd \& Ren, 2009).

Culture staged for commercial purposes, as well as (most commonly) short and planned stays of tourists prevent an actual intercultural communication and interaction. However, for tourism professionals, knowledge of cultural patterns and intercultural communication should represent basic skills.

When it comes to teaching of foreign languages within tourism curricula, developing intercultural competence appears to be even more necessary, as it is one of the most important extralinguistic benefits of learning a foreign language.

Unlike purely linguistically-oriented foreign language teaching, the teaching oriented towards acquiring of business competences in the field of tourism represents a specific form of interactive situation from which an entire series of didactic reflections can be derived. Communicative models of teaching presume that grammar units should be integrated into certain thematic contexts that should, in the case of foreign language curricula in tourism, be oriented towards acquiring intercultural competences, as well. As opposed to this, cognitively oriented research of foreign languages emphasizes that formal language structures in the communicative and meaning-oriented teaching are acquired as incomplete, unless special attention is paid to them.

Business-oriented teaching of foreign languages in tourism should primarily be directed towards content, with reactive and proactive focus on the form. The premise of such a form of teaching is often the presumption that the target language is acquired without explicit explanations. However, numerous research has indicated that targeted content teaching stimulates language acquisition (Bosch Roig, 2012).

Theme units in the field of tourism offer many opportunities to integrate grammar units into a meaningful thematic framework. Thus, for example, spatial prepositions or modal verbs can be very successfully integrated in the topic of landmarks at a destination. Grammar units should thus not be a priori introduced as topics in certain communication contexts, but should be present from the beginning to the end and thematised as and when necessary. However, this is just the first step towards successful teaching of foreign languages in tourism. This form of teaching should simultaneously develop intercultural competences, as well, seeing as we believe that communicative models of teaching with an emphasis on intercultural competences can yield best results in acquisition of foreign languages for tourism professions. In the process of acquiring a foreign language, it is important to be aware of its cultural aspects, as familiarity with other cultures does not only facilitate learning a language, but also allows access to values of that language. Very often, even besides excellent grammatical and lexical competences, misunderstandings happen precisely because of failure to understand different cultural patterns, and tourism professionals can very easily find themselves in such situations, primarily due to the nature of their jobs. Petrovska (2010) emphasizes that such misunderstandings can arise from the lack of knowledge of cultural differences between two (or more) societies or the influence of their mother tongues and direct meaning transfer into the other language. For a successful communication in tourism, it is very important 
to overcome deeply rooted stereotypes about various cultures and nations. It is precisely the intercultural competence that includes the ability to link the culture of origin and the foreign culture, as well as to overcome cultural stereotypes.

Content-oriented teaching can be understood both as a conceptual and as a methodological principle, seeing as it concerns creating a linguistically meaningful context, which offers enough implicit and explicit input and which is actively co-created by students themselves. Implicit learning, in addition to the explicit one, cannot be neglected as an important principle of language acquisition. This kind of language acquisition entails an environment based on content and inputs that offers a qualitatively and quantitatively adequate linguistic content. The more frequently and intensively the students participate in natural and meaning-oriented situations, the faster and more efficiently will they acquire the target language.

In addition to intercultural competences, well-organised lessons of foreign languages for students of tourism would have to develop pragmatic and sociolinguistic competences, as well. In addition to this, when speaking of pragmatic competences, one needs to differentiate between discourse competences and functional competences. In our case, this would mean that students are taught to independently construct parts of written or verbal text (discourse competence), such as, e.g. composing business emails, making phone calls, etc. Functional competence allows for communication in certain situations and specific needs for working in tourism can be addressed by practicing different situations: at the reception, in the agency, in the role of a tour guide, etc.

Contrary to this, sociolinguistic competence should teach future tourism professionals to successfully manage social relations. More precisely, they should be able to choose the most suitable form of communication in relation to the social context in which they find themselves. Seeing as tourism entails a constant interaction with people, this aspect should not be omitted.

The mentioned competences, pragmatic and sociolinguistic alike, should correlate with culturalcommunicological competence. Only the students who acquired those competences can be deemed trained to work in tourism (naturally, in addition to knowledge of other fields, which is implied).

\section{Conclusion}

With the ever-changing processes that permeate tourism, as a multi-faceted and transdisciplinary field, different needs of the industry surface, while motivations to travel and engage in intercultural exchange become even more diverse. In order for language to actually reflect all of these changes, it is necessary to integrate intercultural competences in foreign language teaching, as they not only complete linguistic competences, but, allowing for meaningful interactions, make up an essential part of learning of foreign languages.

Seeing as tourism is inextricably linked with understanding of cultural patterns, it appears that intercultural competence should occupy a central position in teaching of foreign languages. Judging by the tendencies so far, it can be inferred that with the development of socioeconomic aspects of tourism, the needs and modes of usage of intercultural competence are going to evolve, too. Thus, it is with reasonable certainty that one can predict changes in the future patterns and models of both teaching and acquisition of intercultural competence.

Language in tourism can thus be deemed a sociological phenomenon that continues to evolve into the $21 \mathrm{st}$ century and its teaching in the future is tasked with reflecting this.

\section{STATEMENT}

In their statements, the authors confirmed the absence of any conflict of interest.

\section{REFERENCES}

ACTFL. (2006). Standards for foreign language learning in the 21 st century (3rd ed.). Yonkers, NY: National Standards in Foreign Language Education Project.

Blayhl, W. (1994). Das Lernen von Fremdsprachen ist interkulturelles Lernen. In Bausch, K.R., Christ, H., \& Krumm. H.J. (Eds.) Interkulturelles Lernen im Fremdsprachenunterricht. Arbeitspapiere der 24. Frühjahrskompetenz zur Erforschung des Fremdsprachenunterrichts (pp. 9-20). Tübingen: Gunter Narr Verlag.

Bosch Roig, G. (2012). Aufgabungorientierung mit proaktiver Formfokussierung als didaktisches Konzept für den Deutschunterricht im Tourismus. Iberica 23, 157-171. 
Tomić, M., Čolić, D. - The importance of intercultural competence in foreign language teaching 2019. Fakultet za sport i turizam, Novi Sad, Tims.Acta 13, 99-105

Božinović, N., \& Sindik, J. (2013). Language Proficiency for Careers in Tourism and Learning Different Second Foreign Languages. Turizam 17(3), 121-130.

Čolić, D., \& Tomić, M. (2013). Značaj učenja stranog jezika iz perspektive turističke industrije. Tims Acta 7(2), 137-143.

Deardorff, D. K. (2006). Identification and Assessment of Intercultural Competence as a Student Outcome of Internationalization. Journal of Studies in International Education 10(3), 241-266.

European Commission. (2018). Commission Staff Working Document, Accompanying the document "Proposal for a Council Recommendation on a comprehensive approach to the teaching and learning of languages", Brussels https://eur-lex.europa.eu/legal-content/EN/TXT/ HTML/?uri=CELEX:52018SC0174\&from=EN, 17.11.2018.

Fantini, A. E. (2000). A Central Concern: Developing Intercultural Competence. SIT Occasional Paper Series. Retrieved from http://www.sit.edu/publications/docs/competence.pdf, 23.9.2019.

Gardner, G.H. (1962). Cross-cultural communication. Journal of Social Psychology, 58, 248.

Holly, D. (1990). "The Unspoken Curriculum - or How Language Teaching Carries Cultural and Ideological Messages" In Harrison, B. (ed.) "Culture and the Language Classroom", ELT Documents 132. (pp. 11-19). Modern English Publications in association with the British Council.

$\mathrm{Hu}, \mathrm{A}$. (2010). Interkulturelle kommunikative Kompetenz. Handbuch Fremdsprachenunterricht, 2010,75-78.

Knowles, M., \& Kramsch, C. (1995). Context and Culture in Language Teaching. The Modern Language Journal, 79(4), 565. doi: $10.2307 / 330013$

Liburd, J. J., \& Ren, C. (2009). Selling difference: Conceptualising culture in tourism education and management. In M. Blasco, \& M. Zølner (Eds.), Teaching Cultural Skills: Adding culture in higher education, Samfundslitteratur.

Petrović, A. (2011). Interkulturelle Kompetenz im Fremdsprachenunterricht - Probleme und Perspektive der Curriculumentwicklung. Retrieved from https://www. semanticscholar.org/paper/Interkulturelle-Kompetenz-im\%E2\%80\%93-Probleme-und-der-Petravi\%C4\%87/5cc02a268b 23ac5b3376c493efbaac76635c8f00, 26.09.2019.

Petrovska, I. (2010). Teaching and Learning Pragmatics: Speech Strategies for HR Employers, Faculty of Tourism and Management in Opatija. Bienniall International Congress. Tourism and Hospitality Industry. 1142-1149.

Rathje, S. (2006). Interkulturelle Kompetenz - Zustand und Zukunft eines umstrittenen Konzepts. Zeitschrift für Interkulturellen Fremdsprachenunterricht 11(3).

Thomas, A. (2003). Interkulturelle Kompetenz - Grundlagen, Probleme und Konzepte. Erwägen, Wissen, Ethik 14(1), 221228.

Thurlow, C. \& Jaworsky, A. (2010). 'Conclusions' In Thurlow and Jaworsky (Eds), Tourism Discourse. Palgrave Macmillan.

Valdes, J. (1990). "The inevitability of teaching and learning culture in a foreign language course." In Harrison, B. (Ed.) "Culture and the Language Classroom", ELT Documents, 132. (pp. 20-30). Modern English Publications in association with the British Council.
Datum prijave: 29.10.2019.

Datum prihvatanja: 26.11.2019.

\section{Kontakt}

Mladen Tomić, Fakultet za sport i turizam, Radnička 30a, 21000 Novi Sad,

E-mail:mladen.tomic@tims.edu.rs

Danijela Čolić, Fakultet za sport i turizam,

Radnička 30a, 21000 Novi Sad,

E-mail: danijela.colic@tims.edu.rs 